DIRK FRANKEN • ATTILA KARAKUŞ • JAN G. MICHEL

JOHN R. SEARLE

Thinking about the Real World 

I3. Münstersche Vorlesungen zur Philosophie $\mathrm{I}^{\text {th }}$ Münster Lectures on Philosophy

mit/with

\section{JOHNR. SEARLE}



DIRK FRANKEN • ATTILA KARAKUŞ • JAN G. MICHEL (EDS.)

\section{John R. Searle Thinking about the Real World}

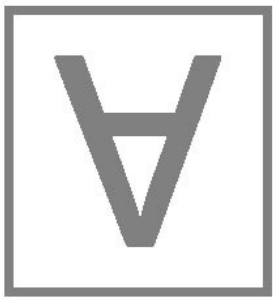

ontos

verlag

Frankfurt I Paris I Lancaster I New Brunswick 
Bibliographic information published by the Deutsche Nationalbibliothek

The Deutsche Nationalbibliothek lists this publication in the Deutsche Nationalbibliografie; detailed bibliographic data are available in the Internet at http://dnb.d-nb.de.

Typeset in Adobe Garamond Pro by Jan G. Michel.
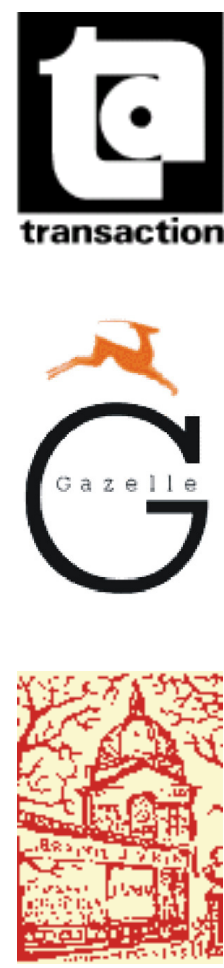

North and South America by

Transaction Books

Rutgers University

Piscataway, NJ 08854-8042

trans@transactionpub.com

United Kingdom, Ire Iceland, Turkey, Malta, Portugal by

Gazelle Books Services Limited

White Cross Mills

Hightown

LANCASTER, LAI 4XS

sales@gazellebooks.co.uk

Livraison pour la France et la Belgique:

Librairie Philosophique J. Vrin

6 , place de la Sorbonne; F-75005 PA R Is

Tel. +33 (o)I $43540347 \cdot$ Fax +33 (o)I 435448 I8

www.vrin.fr

(C) 2010 ontos verlag

P. O. Box I5 4I, D-63133 Heusenstamm nr. Frankfurt

Tel. ++(49) 6ro4 $665733 \cdot$ Fax ++(49) 6ro4 665734

www.ontosverlag.com

ISBN 978-3-86838-096-5

2010

No part of this book may be reproduced, stored in retrieval systems or transmitted in any form or by any means, electronic, mechanical, photocopying, microfilming, recording or otherwise without written permission from the Publisher, with the exception of any material supplied specifically for the purpose of being entered and executed on a computer system, for exclusive use of the purchaser of the work

Printed on acid-free paper Iso-Norm 970-6

FSC-certified (Forest Stewardship Council)

Printed in Germany

by buch bücher.de 